\title{
Propagation of 285-year-old alley linden (Tilia $\times$ vulgaris) trees via long cuttings
}

\author{
T. Winkelmann ${ }^{1}$, W. Spethmann ${ }^{1}$ and A. Seegert ${ }^{2}$ \\ ${ }^{1}$ Leibniz Universität Hannover, Institute of Horticultural Production Systems, Woody Plant and Propagation Physiology, \\ Hannover, Germany \\ ${ }^{2}$ Leibniz Universität Hannover, Institute of Landscape Architecture, Hannover, Germany
}

\begin{abstract}
Summary
The historical linden (Tilia $\times$ vulgaris) alley of the Berggarten Hannover was planted in 1726/1727 and is a famous element of this botanical garden. However, due to reduced viability and reasons of public safety, several trees or the whole alley need to be chopped down in the near future. This study aimed to preserve these historical trees on their own roots by long cutting propagation. Long cuttings were sampled at two positions (base and crown) from 153 trees in July 2012, treated with rooting powder containing $0.5 \%$ indole butyric acid and set for rooting under high-pressure fog conditions. Despite the old age of the mother trees, an unexpectedly high percentage (83\%) of the 1,194 cuttings formed adventitious roots that did not depend on the vitality of the mother trees or the cutting position. However, basal cuttings were superior in the survival of the first season in the field, with $55 \%$ compared to only $36 \%$ of cuttings taken from the crown. The plants, representing 140 mother trees, were observed in more detail, and the majority showed vigorous growth, reaching a height of $1.5 \mathrm{~m}$ in 2014 and $3.3 \mathrm{~m}$ in 2016. Significant differences in height growth and diameter at breast height were recorded for cuttings from the base compared to those from the crown, with better growth of the basal cuttings. After 7 years, in 2019, genotypes of 140 trees were successfully preserved using autovegetative propagation from long cuttings.
\end{abstract}

Keywords

adventitious root formation, historic genotypes, survival, topophysis, tree growth

\section{Introduction}

In 1726/27, E.A. Charbonnier planted an alley with four rows of lindens in the Berggarten, continuing the central axis south from the Great Garden and the centre of the Herrenhausen Palace to the north. The first crown reduction of the lindens was performed in 1784. From 1842 to 1847 , the Mausoleum of the Welfen family was built following the plans by G. Laves, creating the northern terminal point of the alley. At that point, the alley was formed by 215 common lindens (Tilia $\times$ vulgaris). During that construction phase, the tree canopies were pruned again to maintain the visual axis to the Mausoleum. New growth and main branches (larger than $10 \mathrm{~cm}$ in diameter) were trimmed regularly every 30 to 40 years until 1943 . Today, the 293-year-old alley with

\section{Significance of this study}

What is already known on this subject?

- With increasing age vegetative propagation of trees becomes more difficult or even impossible. Topophysis indicates that basal cuttings are physiologically juvenile.

What are the new findings?

- High rooting percentages were observed for long softwood cuttings from 285 -year-old Tilia $\times$ vulgaris trees. The topophysis effect was seen in better survival and growth.

What is the expected impact on horticulture?

- Since more than $91 \%$ of the trees were successfully propagated on their own roots, the findings are useful for preserving the germplasm of trees of historical importance.

four rows of mature lindens is a major feature of the Berggarten (Figure 1A). The numerous pruning events left large cutting wounds on the main branches, which created various structural problems on the inside of the trees, such as wood rot, bark cracks, necrotic tissue, and very small residual wall thickness. In the 1990s, a number of discussions about traffic and work safety in the alley took place within the garden management. These discussions led to a major crown reduction in 1994 during which each tree was trimmed by 10 to $20 \mathrm{~m}$ to a final crown height of $6 \mathrm{~m}$. From then on, new growth was cut back and thinned out every 3 to 4 years to reduce the risks of breakage. Despite these efforts, the danger of wood rot increased such that the main branches of 55 linden trees were cut back drastically in 2008. Between 2009 and 2012, 33 trees of the 171 existing original lindens were removed completely after internal and external inspections and analyses due to traffic safety concerns. Of the remaining trees, 15 were cut back almost completely to their trunk. In 2009 , in an assessment of the vitality of the linden alley of the Berggarten, a complete replanting after growing suitable replacement trees was recommended (Balder, 2009).

In the decision-making process, the interests of historical preservation, traffic and work safety, and visitor experience and satisfaction had to be considered. An expert colloquium held in 2012 at Herrenhausen revealed different viewpoints within the historical preservation community. Some were of the opinion that each tree should be preserved as a living testimony until its natural death. Others preferred a complete replanting of a homogeneous alley to recreate the original 

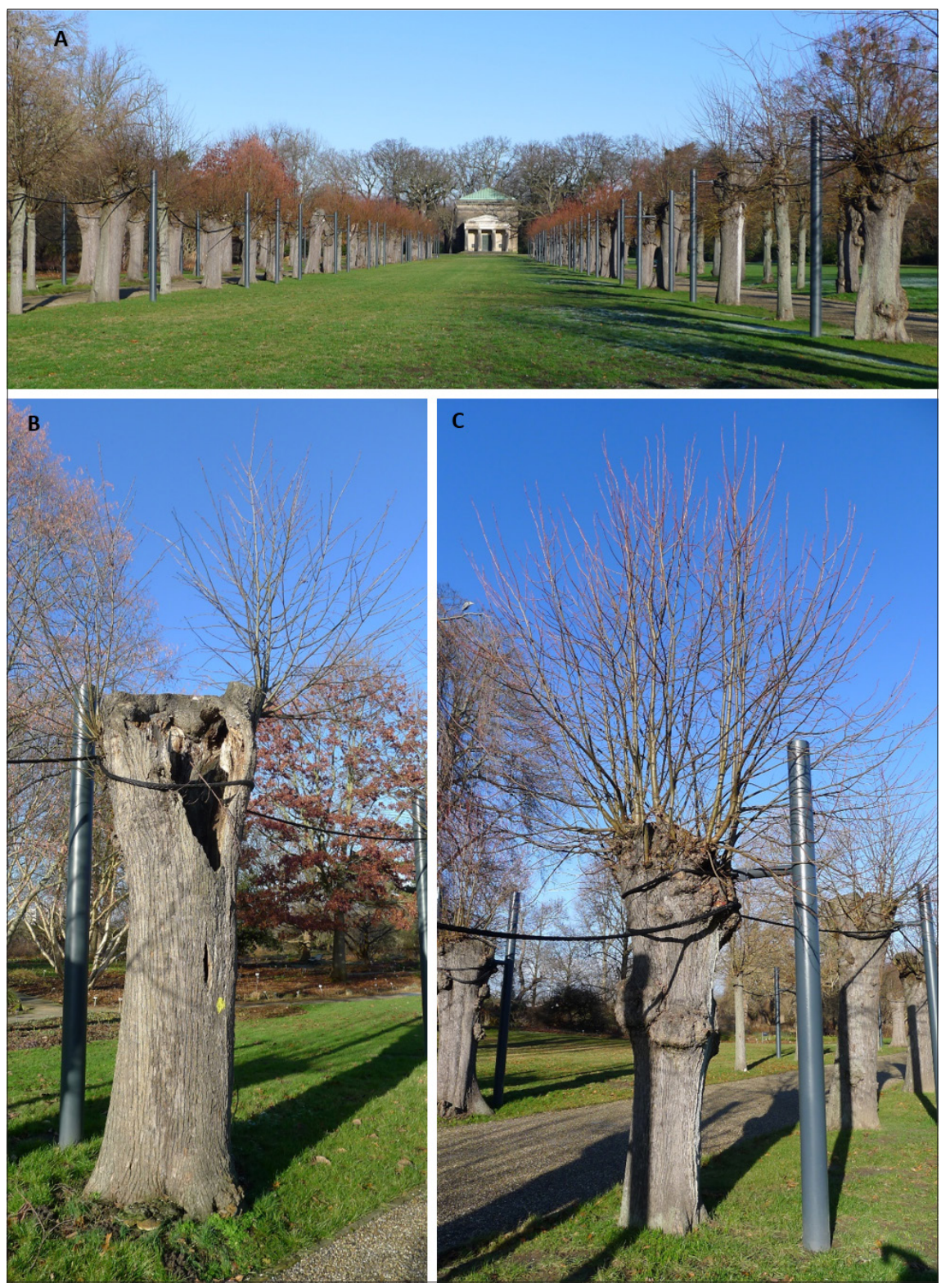

FIGURE 1. Historical linden alley of the Berggarten Hannover in January 2019 (A) with Tilia $\times$ vulgaris trees of strongly reduced vitality (B) or full vitality (C). The trees had been pruned in 2015/2016 after the collection of the cuttings.

state under the condition of keeping a few original trees as witnesses of time that were to be replaced at a later time with genetically identical trees. Thus, long cuttings were taken of each linden in 2012 to test this approach.

Simultaneously, the planning process for the replanting of the alley was meant to begin during the winter of 2013/14 (Seegert, 2011), which included the assessment routinely required according to species protection legislation. Shortly before the first felling in the fall of 2013, it was shown that hermit beetles (Osmoderma eremita) existed in several of the potential habitat trees (Dr. P. Sprick, personal communication; Kuruppu, 2015). These beetles are strictly protected as a priority species according to Article 7 (2) No. 14 b of the German Federal Nature Conservation Law (Bundesnaturschutzgesetz = BNatSchG) and Addendum No. II and No. IV of the European Flora and Fauna Habitat directive (FFH-Richtlinie) (EC 105 2006). The hermit beetle is an umbrella species for other strictly protected carabid beetles. The deterioration of its living conditions by any project is strictly prohibited by law. The population of the hermit beetle can be considered the second largest in Lower Saxony (Kuruppu, 2015). The felling of the trees of the linden alley is neither permitted nor approvable as per the German Federal Nature Conservation
Law (BNatSchG) due to the hermit beetle and two other species native only to natural forests (Urwaldreliktart), as well as 27 endangered wood-inhabiting species. The city of Hannover will therefore preserve and maintain the 138 linden trees in the Berggarten alley as a potential habitat until their natural death. It is conceivable that the hermit beetle could be relocated into other existing habitats in the larger region of Hannover. This relocation can only be implemented once there is scientific proof that a relocation is indeed successful and the new habitat has been permanently adopted by the hermit beetle past its larval stage.

The linden alley was closed for a while to the public and staff of the Herrenhausen Gardens, while 128 partially unsafe trees were each secured via ropes to metal support structures (Figure 1A). Before installing the ropes and support structures, the trees were pollarded in 2015 and 2016 to prevent the hollow main branches from breaking apart.

Genetic analyses by DNA markers revealed that some of the trees had been grafted, while others were seedlings. Overall, high genetic heterogeneity was revealed. The Tilia species could not be determined by these investigations, but it seemed likely that they were hybrids (T. × europaea syn. T. × vulgaris; presumably natural hybrids of T. cordata and T. platyphyllos). 
As explained above, this study aimed to preserve the germplasm of the Berggarten linden alley on its own roots by cuttings. Several parameters are known to affect the rooting of tree cuttings, such as genotype, age, position, length, collection date, rooting conditions, substrate, or auxin treatment (Osterc and Stampar, 2008; Pijut et al., 2010; Hartmann et al., 2011; Druege et al., 2019). Among these parameters, age is of outstanding importance, often impeding adventitious root formation of cuttings from mature trees. Spethmann $(1998,2005,2015)$ observed higher rooting percentages for cuttings from adult trees if long cuttings, i.e., cuttings with a minimum length of $40-50 \mathrm{~cm}$ and up to more than $100 \mathrm{~cm}$, were used, taken in June or July and rooted in a high-pressure fog system. The physiological age and rooting ability of a cutting is determined not only by the chronological age of the mother tree but also by its position because, according to the topophysis phenomenon, basal plant parts remain physiologically young (Roulund, 1973; Osterc et al., 2016).

The aim of this study was to preserve as many Tilia $\times$ vulgaris genotypes of the historical linden alley as possible by autovegetative propagation. Therefore, our objectives were (i) to compare the root formation of long cuttings taken at two positions, the base and the crown region of these 285-year-old trees; (ii) to monitor their survival in the field; and (iii) to observe their growth characteristics during the first six years in the nursery.

\section{Materials and methods}

Cuttings were collected at the end of July 2012 from 153 trees differing in their vitality or safety status (Table 1, Figure 1) and, if possible, from two positions: basal shoots or suckers and cuttings taken from vertical shoots in the crown region at a height of 2-3 $\mathrm{m}$. The cuttings had fresh green younger and dark green older leaves and did not show any signs of yellowing (Figures 2A and B). For the majority of the 153 trees, molecular markers had shown that samples taken at the crown part and the basal part had the same genetic constitution, whereas for few plants different marker patterns were observed for basal and crown parts, indicating that they had been propagated by grafting. Overall, the material harvested represented a high variation of different genotypes. For 10 trees, only cuttings from the base were
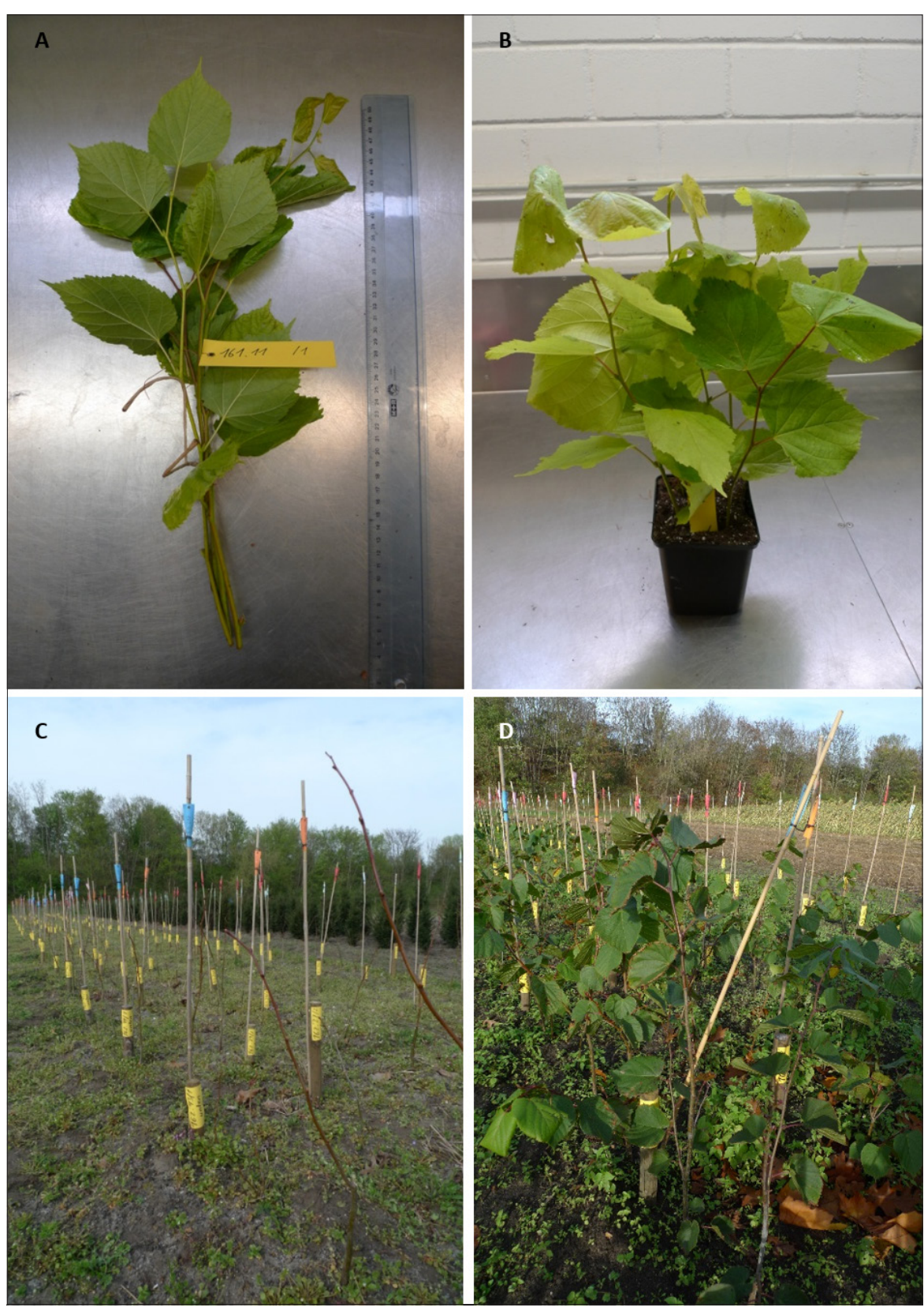

FIGURE 2. Long cuttings prepared for sticking (A) and after sticking (B) in August 2012. Rooted cuttings after the first winter in April (C) and October (D) 2013. 
TABLE 1. Number of trees in the different vitality and safety classes and their survival during the first year.

\begin{tabular}{lccc}
\hline Vitality class of the linden trees & $\begin{array}{c}\text { Number of } \\
\text { mother trees }\end{array}$ & $\begin{array}{c}\text { Number of trees with cuttings } \\
\text { surviving the first year }\end{array}$ & $\begin{array}{c}\text { Number of trees successfully } \\
\text { preserved until 2019 }\end{array}$ \\
\hline Fully or predominantly vital & 85 & 77 & 77 \\
Reduced vitality or safety & 53 & 52 & 52 \\
Cut down after harvest of cuttings & 15 & 13 & 11 \\
\hline Sum & 153 & 142 & 140 \\
\hline
\end{tabular}

${ }_{1}^{1}$ Trees had partly decayed trunks and showed signs of fungal infection.

available; for 4 trees, only cuttings from the crown were harvested, because these trees did not produce shoots at their base; and for 138 trees, cuttings were available from both positions. Thus, in 14 cases, cuttings were only harvested from one position. In addition, the desired number of 5 cuttings per position and tree could not be achieved, so a total of 1,442 cuttings was taken on 24.07.2012. Therefore, approximately one half (737) were derived from the base and 705 from the crown of the trees.

Cutting propagation followed the methods described earlier (Spethmann, 1998, 2005, 2008). The cuttings had a mean length of $50 \mathrm{~cm}$ (Figure 2A). The leaves were removed from the base of each cutting (at a length of approximately $10-15 \mathrm{~cm}$ ). Freshly cut surfaces were dipped into rooting powder $(0.5 \%$ indole butyric acid in talc powder) directly before sticking. The substrate was composed of white peat and sand $(3: 1, \mathrm{v}: \mathrm{v})$, and $\mathrm{CaCO}_{3}$ was added to adjust the $\mathrm{pH}$ to 4.5-5.0. Mixed with a slow-release fertilizer $\left(2 \mathrm{~g} \mathrm{~L}^{-1}\right.$ Osmocote exact 3-4M; $16+9+12+2 \mathrm{Mg0}$; ICL Specialty Fertilizers, www.icl-sf.com), the substrate was used to fill 1-L containers $(11 \times 11 \mathrm{~cm}$ pots for perennials). Five cuttings were placed into one pot where available because a very low rooting percentage had been expected.

All pots were placed on the ground of a polyethylene tunnel at Leibniz Universität Hannover, Germany, with high humidity provided by high-pressure fog. Fog (Plantfog system) pulses were given for one minute every 10 min during the first four weeks, followed by 1 min every 15 min for four weeks and 1 min every 30 min until the fog was completely stopped at the end of September 2012. The relative humidity was $90-100 \%$ during the first four weeks, accompanied by high temperatures on sunny days of up to $40^{\circ} \mathrm{C}$. Infections with fungal diseases were not observed. In October, the cuttings were transferred to a greenhouse and overwintered by keeping the temperatures above $0^{\circ} \mathrm{C}$.

On 07.05.2013, rooting was evaluated for each cutting, and the rooted cuttings (1,194 in total) were planted (without pots) in a field at the municipal nursery of the city of Hannover (Table 2). On 28.08.2013, the survival of the plants in the field was recorded. The length of each plant was measured on 03.04.2014 (representing the length of the year 2013 in the results) and on 28.08.2014 (for the year 2014).

All living plants exceeding $100 \mathrm{~cm}$ in height (444 in total) were transplanted again in April 2015 to a second stand at the municipal nursery (Table 2). To document the additional growth of the trees, their total length was taken on 27.10.2015 and on 05.10.2016. Thereafter, for some trees, the main stems had to be pruned at 3-4 m, for the first time. On 27.10.2015, 05.10.2016 and 27.10.2017, the stem diameter at breast height $(1.3 \mathrm{~m})$ was taken.

In April 2018, 335 trees, which were considered to have the potential to become alley trees, were transplanted again to a third site in close proximity to the first two sites (Table 2). Care was taken to preserve as many genotypes as possible, and the strongest one to two plants of each tree-position combination were selected for transplantation. All

TABLE 2. Cultivation and growing conditions in the tree nursery of the Tilia $\times$ vulgaris plants derived from cuttings.

\begin{tabular}{|c|c|c|c|}
\hline & $\begin{array}{l}\text { Stand 1: } \\
07.05 \text { 2013-14.04.2015 }\end{array}$ & $\begin{array}{l}\text { Stand 2: } \\
15.04 .2015-08.04 .2018\end{array}$ & $\begin{array}{l}\text { Stand 3: } \\
\text { since 09.04.2018 }\end{array}$ \\
\hline GPS data & Latitude, Longitude 52.4280, 9.7833 & Latitude, Longitude 52.4280, 9.7836 & Latitude, Longitude: $52.4287,9.7917$ \\
\hline Soil type & Podsol-gley & Podsol-gley & Podsol \\
\hline Soil texture & Sand & Sand & Sand \\
\hline Soil preparation & $\begin{array}{l}\text { Starting } 2 \text { years before planting: } \\
\text { compost, green manure, horse manure, } \\
\text { plough, rotary cultivator, grubber }\end{array}$ & $\begin{array}{l}\text { Starting } 2 \text { years before planting: } \\
\text { compost, green manure, horse manure, } \\
\text { plough, rotary cultivator, grubber }\end{array}$ & $\begin{array}{l}\text { Starting } 2 \text { years before planting: } \\
\text { compost, green manure, horse manure, } \\
\text { plough, rotary cultivator, grubber }\end{array}$ \\
\hline Spacing & $0.5 \mathrm{~m} \times 0.25 \mathrm{~m}$ & $1 \mathrm{~m} \times 0.5 \mathrm{~m}$ & $2 m \times 2 m$ \\
\hline Fertilization & $\begin{array}{l}40 \mathrm{~g} \mathrm{~m}^{-2} \text { Patentkali } \\
\text { (March 2014) } \\
35 \mathrm{~g} \mathrm{~m}^{-2} \text { Blaukorn classic } \\
\text { (April 2014) }\end{array}$ & $\begin{array}{l}40 \mathrm{~g} \mathrm{~m}^{-2} \text { Patentkali1 } \\
\text { (March 2015, 2016, 2017) } \\
35 \mathrm{~g} \mathrm{~m}^{-2} \text { Blaukorn classic } \\
\text { (April 2015, 2016, 2017) }\end{array}$ & $\begin{array}{l}40 \mathrm{~g} \mathrm{~m}^{-2} \text { Patentkali } \\
\text { (March 2018) } \\
35 \mathrm{~g} \mathrm{~m}^{-2} \text { Blaukorn classic } \\
\text { (May 2018) }\end{array}$ \\
\hline $\begin{array}{l}\text { Culture } \\
\text { management }\end{array}$ & $\begin{array}{l}\text { Pruning at planting } \\
\text { Pruning and fixing: February } 2014 \text {, } \\
\text { May } 2014, \text { February } 2015 \\
\text { Mechanical and manual weeding, } \\
\text { every 6-8 weeks, no herbicides }\end{array}$ & $\begin{array}{l}\text { Pruning at planting } \\
\text { Pruning and fixing: July } 2015 \text {, } \\
\text { February 2016, July 2016, February } \\
2017 \text {, July 2017, February } 2018 \\
\text { Mechanical and manual weeding, } \\
\text { every } 6-8 \text { weeks, no herbicides }\end{array}$ & $\begin{array}{l}\text { Pruning at planting } \\
\text { Mechanical and manual weeding, } \\
\text { every } 6-8 \text { weeks, no herbicides }\end{array}$ \\
\hline
\end{tabular}

${ }^{1}$ Patentkali: $30 \% \mathrm{~K}_{2} \mathrm{O}, 10 \% \mathrm{MgO}, 42.5 \% \mathrm{SO}_{3}, \mathrm{~K}+\mathrm{S}$ Kali GmbH, Kassel, Germany.

${ }^{2}$ Blaukorn classic (solid state): $\mathrm{N}+\mathrm{P}_{2} \mathrm{O}_{5}+\mathrm{K}_{2} \mathrm{O}(+\mathrm{MgO}+\mathrm{S}): 12+8+16(+3+10), 0.02 \% \mathrm{~B}, 0.06 \% \mathrm{Fe}, 0.01 \% \mathrm{Zn}$, Compo Expert GmbH, Münster, Germany. 
TABLE 3. Rooting success and survival potential depending on the vitality class and origin of the cuttings of Tilia $\times$ vulgaris.

\begin{tabular}{llccccc}
\hline Vitality class & & $\begin{array}{c}\text { Number } \\
\text { of } \\
\text { cuttings } \\
24.07 .2012\end{array}$ & $\begin{array}{c}\text { Number of } \\
\text { cuttings rooted } \\
\text { and planted } \\
07.05 .2013\end{array}$ & $\begin{array}{c}\text { Rooting } \\
(\%)\end{array}$ & $\begin{array}{c}\text { Survival } \\
28.08 .2013\end{array}$ & $\begin{array}{c}\text { Survival } \\
(\%)\end{array}$ \\
\hline Fully or predominantly vital & Base & 410 & 335 & 81.7 & 169 & 50.4 \\
& Crown & 425 & 340 & 80.0 & 127 & 37.4 \\
\hline Reduced vitality & Base & 258 & 206 & 79.8 & 118 & 57.3 \\
& Crown & 245 & 230 & 93.9 & 77 & 33.5 \\
\hline Cut down after harvest of cuttings & Base & 69 & 56 & 81.2 & 31 & 55.4 \\
& Crown & 35 & 27 & 77.1 & 10 & 37.0 \\
\hline Sum & & 1,442 & 1,194 & 82.8 & 542 & 45.4 \\
Base & & 737 & 599 & 81.3 & 328 & 54.8 \\
Crown & & 705 & 596 & 84.5 & 214 & 35.9 \\
\hline
\end{tabular}

details regarding soil type, spacing, fertilization and other cultural managements are listed in Table 2.

Statistical analyses were carried out by a one-way ANOVA to test for significant differences between cuttings from the base and from the crown.

\section{Results}

After cultivating the cuttings in a fog house and overwintering them in a cold greenhouse, the first evaluation of the rooting success was carried out in April 2013. The cuttings were uprooted, and over all genotypes and cutting positions, an unexpectedly high rooting percentage of $82.8 \%$ was observed (Table 3). Interestingly, cuttings from basal and crown positions did not differ in their rooting percentage, which was $81.3 \%$ for those taken from the base and $84.5 \%$ for those from the crown. Additionally, a high vitality of the mother trees was not decisive for rooting. Even the trees that were severely reduced in vitality and chopped down after harvesting of the cuttings gave rise to cuttings with rooting success $(80 \%)$ similar to that found for the fully vital trees or trees with reduced vitality, which had to be cut back strongly to guarantee public safety with 83 and $86 \%$ rooting percentage, respectively (Table 3).

Overall, all 1,194 rooted cuttings were planted in the field in April 2013 (Figure 2C), including those that had only a few roots or appeared weak. In August 2013, the surviving trees were noted and measured for the first time (Figure 2D). In total, 542 plants $(45.4 \%)$ survived the first season in the field (Table 3). A pronounced difference in survival ability was observed between the cuttings derived from the base of the trees (54.8\%) and the cuttings taken from the crown (35.9\%). This difference was noted for all mother trees, regardless of their vitality or safety class (Table 3): cuttings from the juvenile basal position survived to percentages of 50.4 to $57.3 \%$, whereas only 33.5 to $37.4 \%$ of the cuttings from the higher positions survived. During the following years, hardly any additional trees died. Because the results obtained for the different vitality classes of the original trees did not differentiate them, the following observations and measurements focused on the effects of the cutting position.

The average length of the plants in autumn 2013 was $50 \mathrm{~cm}$, independent of the original position of the cuttings on the trees (Figure 3). In 2014, nearly all cuttings grew extremely well and increased in height by more than $1 \mathrm{~m}$ on average (Figure 3). The first trees had reached heights of more than $2 \mathrm{~m}$ in autumn 2014 (Figure 4A). Although the variation among the plants was high, as indicated by the standard deviations in Figure 3, the small difference in mean height between cuttings from the base $(163 \mathrm{~cm})$ and the crown cuttings $(149 \mathrm{~cm})$ was significant due to the high number of observations. Following transplantation in spring 2015, a minor increase in plant height of less than $50 \mathrm{~cm}$ was observed, with the difference between plants from basal and crown cuttings becoming larger (Figure 4B). After the second

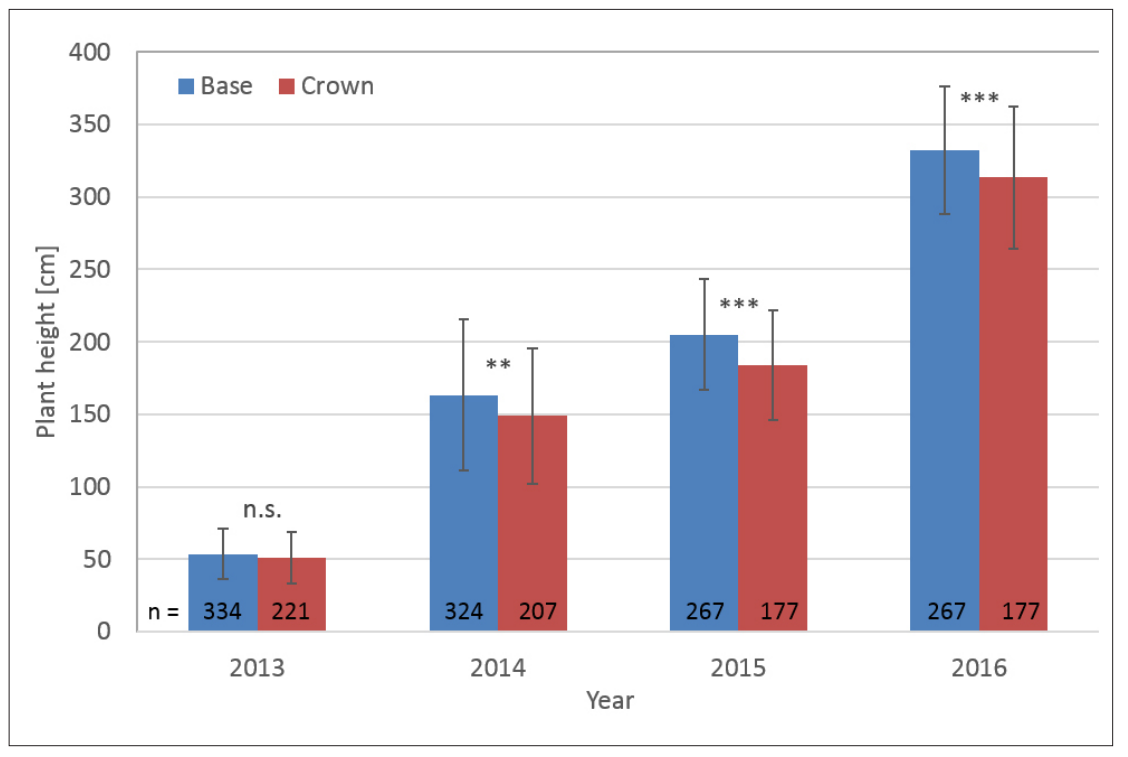

FIGURE 3. Height growth of rooted cuttings during the first four years after setting. Significant differences between cutting positions (base and crown) are indicated based on the p-values from ANOVA, with *: $\mathrm{p} \leq 0.05$, ${ }^{* *}: \mathrm{p} \leq 0.01,{ }^{* * *}: \mathrm{p} \leq 0.001$, and n.s.: not significant. 
vegetation period at the same stand, the first trees were taller than $4 \mathrm{~m}$, still showing active growth with a strong central leader (Figure 4C). The average height of trees of cuttings from the base was $332 \mathrm{~cm}$, which was nearly $20 \mathrm{~cm}$ and significantly more than the mean height of $313 \mathrm{~cm}$ measured for trees derived from crown cuttings (Figure 3).

In 2017, pruning of the main stems was performed, so the height measurements were no longer meaningful. As commonly applied in forestry, tree growth was instead described by the diameter at breast height (breast height diameter $=$ BHD) (Figure 5). Corresponding to the height data (Figure 3), the BHD increased strongly over time, indicating the vigorous growth of the plants (Figure 4). Especially in the second and third years after transplantation, large stem diameter increments were observed, leading to average BHD values of $21.5 \mathrm{~mm}$ (cuttings taken from the crown) and $24.5 \mathrm{~mm}$ (cuttings from the base) in autumn 2017. The maximal diameters measured at this time point were 36 and $33 \mathrm{~mm}$ for trees
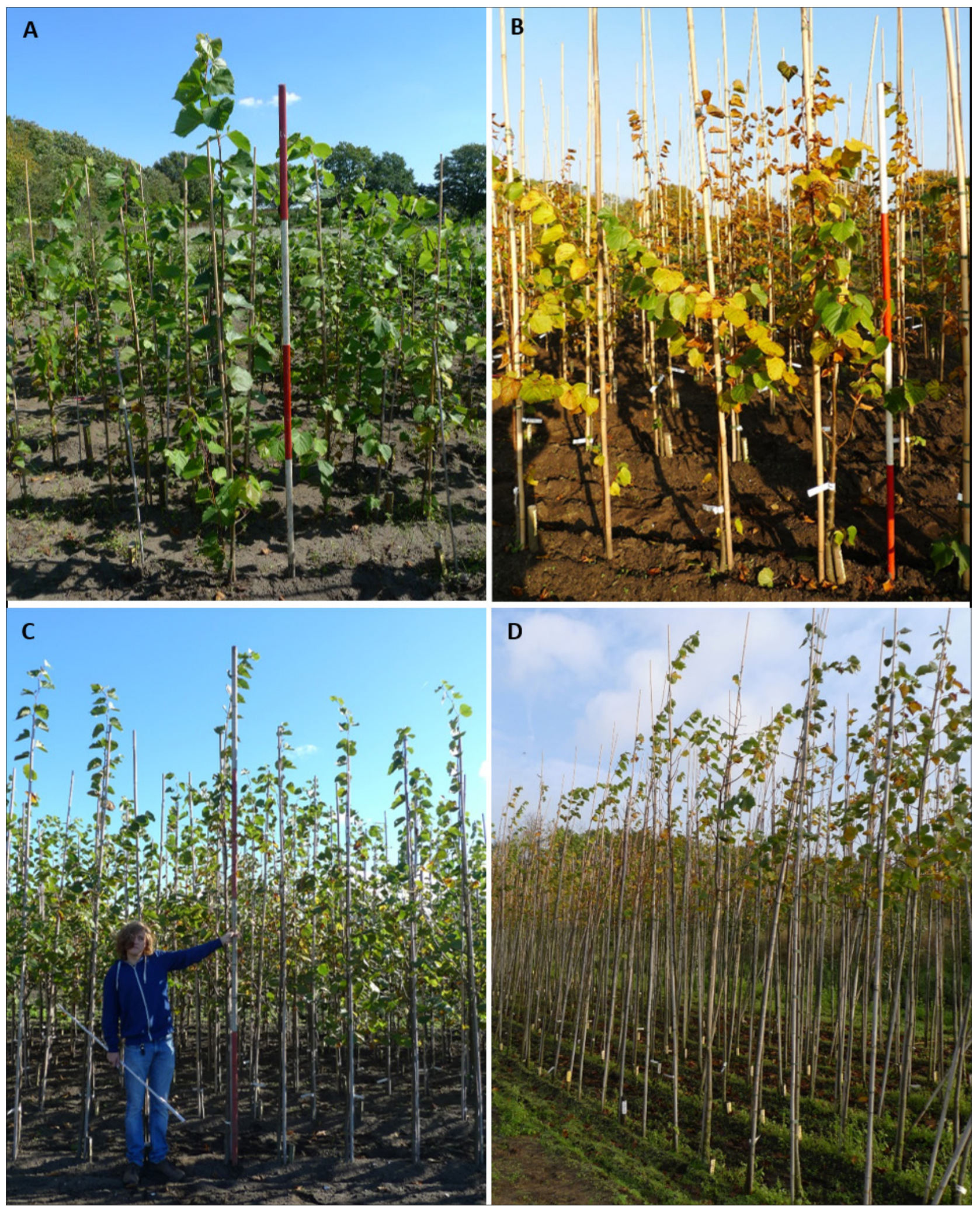

FigURE 4. Appearance of the young trees in August 2014 (A), October 2015 (B), October 2016 (C), and October 2017 (D). 
derived from basal and crown cuttings, respectively, corresponding to circumferences of 11.3 and $10.4 \mathrm{~cm}$, respectively.

Interestingly, the highly significant difference in diameter between cuttings of the two positions increased over time, with trees that had been basal cuttings having thicker stems. The generally better survival of cuttings from the first year and more vigorous growth of the trees derived from basal cuttings are also reflected by the numbers and size of trees selected for transplantation in April 2018 (Table 4). While 138 trees derived from crown cuttings were cultivated further with an average BHD of $22.6 \mathrm{~mm}, 197$ trees derived from basal cuttings were transplanted with a mean BHD of $25 \mathrm{~mm}$ (Table 4).

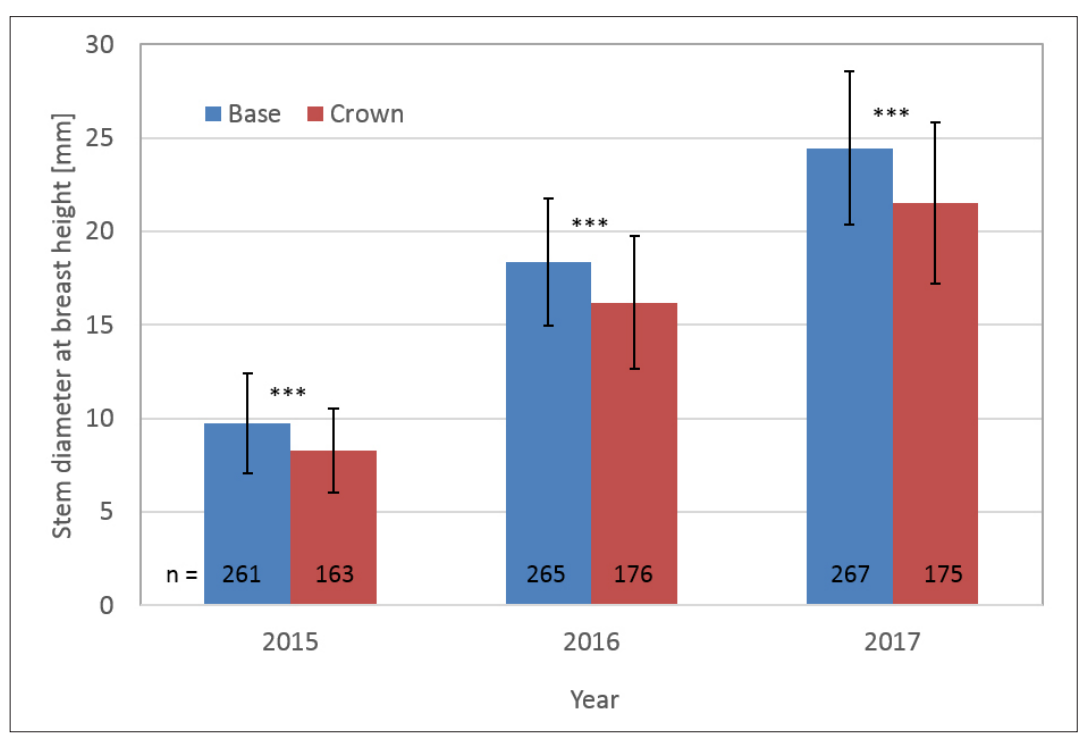

FigURE 5. Increase in stem diameter (taken at breast height $=1.3 \mathrm{~m}$ ) of rooted cuttings between 2015 and 2017. Significant differences between cutting positions (base and crown) are indicated based on the p-values from ANOVA, with $*$ : $\mathrm{p}<0.05,{ }^{* *}: \mathrm{p}<0.01$, and ${ }^{* * *}: \mathrm{p}<0.001$.
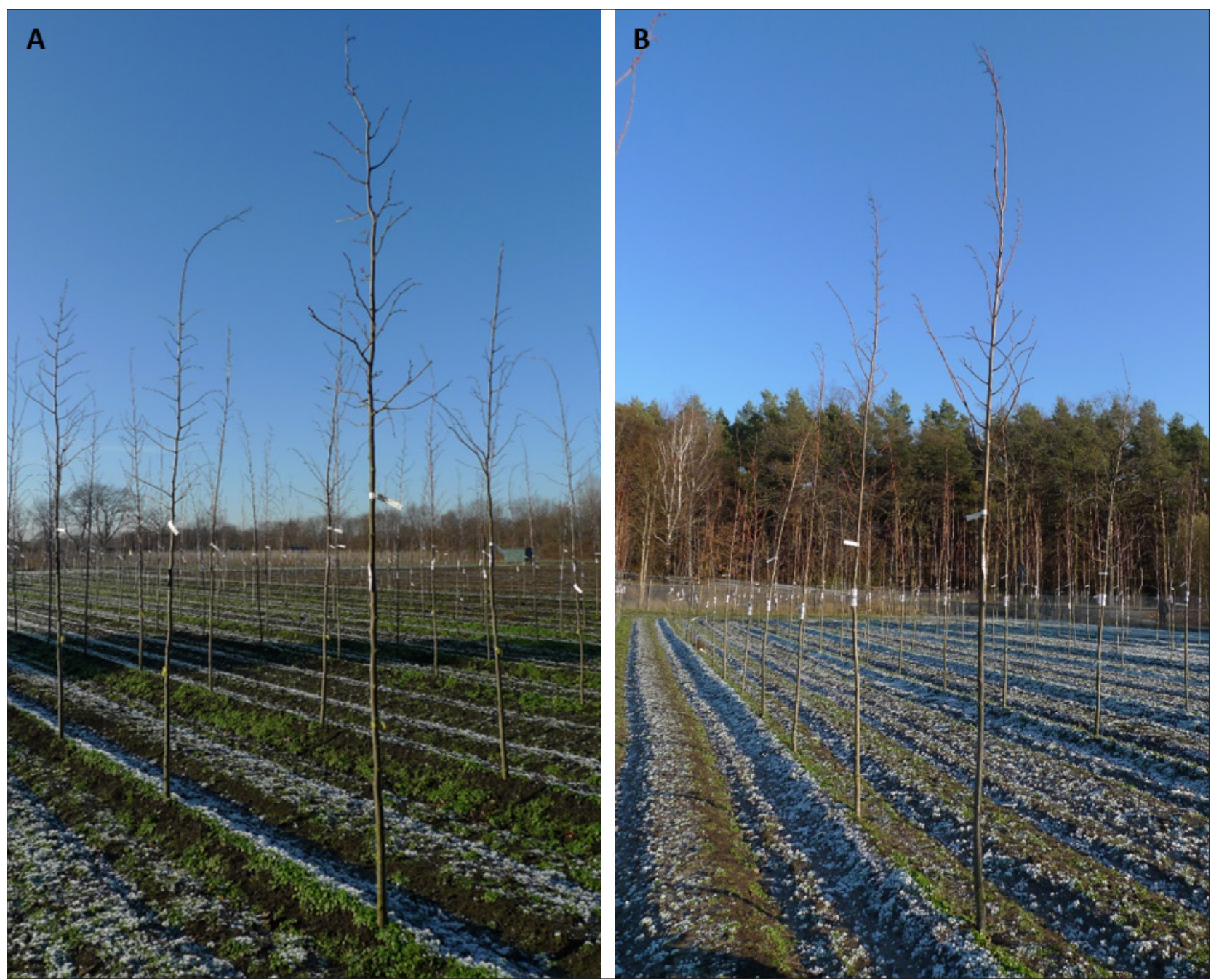

FIGURE 6. Trees from long cuttings in January 2019. Cuttings were taken from the base (A) or the crown (B) of the 285-yearold linden trees. 
TABLE 4. Diameter at breast height (BHD) of the 7-years-old trees from cuttings of Tilia $\times$ vulgaris.

\begin{tabular}{lcccc}
\hline & \multicolumn{2}{c}{ Cuttings from the base } & \multicolumn{2}{c}{ Cuttings from the crown } \\
\cline { 2 - 5 } & Transplanted in April 2018 & Not transplanted & Transplanted in April 2018 & Not transplanted \\
\hline Number & 197 & 70 & 138 & 39 \\
BHD $(\mathrm{mm})$ April 2018: & $25.0 \pm 3.7$ & $22.9 \pm 4.6$ & $22.6 \pm 3.6$ & $17.6 \pm 4.4$ \\
mean \pm SD & & & $22.8 \pm 3.8$ & - \\
BHD $(\mathrm{mm})$ January 2019: & $25.2 \pm 3.9$ & - & $12.0-32.7$ & - \\
mean \pm SD & & & & \\
BHD $(\mathrm{mm})$ January 2019: & $12.0-38.0$ & - & & \\
min.-max.
\end{tabular}

${ }^{1}$ BHD in January 2019 was significantly affected by the cutting position, as revealed by ANOVA $\left(p=5^{*} 10^{-8}\right)$.

In January 2019, strong trees with clear leading stems that were derived from cuttings of both positions were surveyed, showing heights of up to $5 \mathrm{~m}$ and a maximal BHD of $38 \mathrm{~mm}$ (= nearly $12 \mathrm{~cm}$ circumference, Table 4) (Figure 6). Of the 153 old linden trees from which cuttings had been sampled, 140 were successfully propagated and thus preserved (Table 1).

\section{Discussion}

Long cuttings harvested in July 2012 from the very old mother trees formed roots under the fog conditions at an extraordinarily high percentage of $83 \%$, irrespective of the vitality rating of the mother trees. The carbohydrate reserves in the stems of the long cuttings as well as the photosynthetic assimilates produced by the leaves or endogenous production of indole acetic acid by axillary buds that remained on the cuttings until autumn may have contributed to this high rooting success (Spethmann, 2007). Long cuttings of mature trees of different species (Acer, Betula, Quercus, Ulmus, and Tilia) were successfully rooted as reported by Spethmann (2005, 2007). For Tilia cordata, 62-cm-long cuttings from 50 -year-old trees rooted under conditions similar to those applied in the present study also revealed rooting percentages of 83\% (Spethmann, 2005). Like in the present study, long cuttings sampled in June and July were observed to reveal high rooting and overwintering success (Spethmann, 2008).

The auxin treatment ( $0.5 \%$ IBA) can be assumed to further stimulate adventitious root formation. Similarly, a positive effect of cutting length and a dip in $0.5-1.0 \%$ IBA on root growth was reported for Tilia americana (Morsink and Smith, 1974). For Tilia cordata, Klahr and Still (1979) did not observe an effect of relatively high concentrations of IBA (1-3.5 \% IBA applied as a quick dip) on the rooting percentage (approximately 70\%) of cuttings taken from 20-40-yearold mother trees but found a significant improvement in the quality of the root system.

Regarding the age of the mother trees, hardly any scientific data are available in the literature for Tilia ssp. Only Spethmann (1985) sampled conventional (short) cuttings from Tilia cordata trees that were between 2 and 50 years old. He demonstrated a clearly negative effect of increasing mother plant age on the survival of cuttings, which decreased from $80 \%$ for the youngest to only $4 \%$ for the oldest mother trees. The rooting success of the long cuttings taken from the 285-year-old trees in this study was, therefore, unexpectedly high.

An explanation for this may be found in the history of the trees, which was characterized by frequent and severe pruning (Figure 1). This pruning might have resulted in frequent rejuvenation. In agreement with this idea, no dif- ferences in root formation were found between the cutting positions. According to the topophysis effect, basal cuttings, i.e., suckers from the basal part of the trunk, were expected to be easier to root (Roulund, 1973; Osterc et al., 2016). This fact was also described for four Tilia species, among them the parental species of $T$. $\times$ vulgaris, $T$. cordata and T. platyphyllos (Magherini and Nin, 1993), with better rooting success in suckers than shoot cuttings. The frequent pruning of the alley trees may have resulted in rejuvenation of the cuttings that were sampled in the crown positions. Recently, Wang et al. (2011) showed that micro RNAs 156 and 172, that had been identified to be responsible for the transition from the juvenile to the adult growth phase in herbaceous model plants, were also involved in the phase change during maturation and ageing of woody plants. These micro RNAs could be used as markers for age and would allow us to confirm the hypothesis of rejuvenation of the linden trees by pruning.

However, over time, differences in survival and vigour became obvious, showing the position effect very clearly: only $36 \%$ of cuttings sampled from crown positions survived, compared to $55 \%$ of the basal cuttings (Table 3). The growth of the basal cuttings, in terms of plant height (Figure 3) and BHD (Figures 5 and 6), was significantly better, showing the advantages of the juvenile material that can be harvested in the form of suckers at the base of the trees. Tilia cordata cuttings from older mother trees also showed reduced plant heights when compared to juvenile mother trees (Spethmann, 1985). However, since some of the trees were identified as grafts by the genetic analyses (see Introduction), a genotypic effect cannot be excluded here.

The vigorous growth of the Tilia $\times$ vulgaris plants was especially pronounced in the second year after transplantation (Figure 3), whereas in the years of planting and transplantation $(2013,2015)$, smaller increases in height and BHD were recorded due to the transplant shock. The height data were consistent with those described by Spethmann (2005) for long-cuttings of Tilia cordata with 85 and $189 \mathrm{~cm}$ heights for plants one and two years after setting the cuttings.

One main aim of the present study was to preserve the genotypes of the historical alley. Cuttings of all 153 trees were successfully rooted, and plants of 142 trees survived the first year (Table 1). The majority of trees, i.e., 140 out of 153, was successfully preserved until January 2019. For half of the successfully preserved trees (70 trees), plants derived from both positions were available, whereas for 58 and 22 trees, propagation was successfully achieved with cuttings from the base or the crown, respectively.

In conclusion, the present study demonstrated that nearly 300-year-old trees could be successfully propagated on their own roots by long cuttings. High-quality trees were 
produced from the rooted cuttings. The plants obtained continue to be cultivated, as a complete replanting of the linden alley can be expected under the circumstances explained in the Introduction, and it would be desirable to replace at least part of it with plant material of the historic genotypes.

\section{Acknowledgments}

The authors are very grateful to Simon Richartz, Reinhardt Hermann, Casiano Puga-Dominguez and the gardening team of the Berggarten Hannover and the Section of Woody Plant and Propagation Physiology of the Leibniz University Hannover for their excellent cultivation and documentation of cuttings and trees as well as Konrad and Onno Strolka and Hans Bethge for their assistance in taking the measurements. The help of Bianca Wright in translating the description of the history of the alley is gratefully acknowledged.

\section{References}

Balder, H. (2009). Bewertung der historischen Linden-Allee im Berggarten Hannover vor dem Hintergrund der aktuellen Vitalität und Gesundheit. Unpublished expert opinion.

Druege, U., Hilo, A., Pérez-Pérez, J.M., Klopotek, Y., Acosta, M., Shahinnia, F., Zerche, S., Franken, P., and Hajirezaei, M.R. (2019). Molecular and physiological control of adventitious rooting in cuttings: phytohormone action meets resource allocation. Annals of Botany, https://doi.org/10.1093/aob/mcy234.

EC 105 (2006). Council Directive 2006/105/EC. Official Journal of the European Union 20.12.2006, L 363/368, https://eur-lex.europa. eu/eli/dir/2006/105/oj.

Hartmann, H.T., Kester, D.E., Davies, F.T., and Geneve, R. (2011). Plant Propagation: Principles and Practices (Prentice Hall, USA: Pearson), $880 \mathrm{pp}$.

Klahr, M.D., and Still, S.M. (1979). Effect of indolebutyric acid and sampling dates on the rooting of four Tilia taxa. Sci. Hortic. 11, 391397. https://doi.org/10.1016/0304-4238(79)90024-4.

Kuruppu, J. (2015). Erhaltungsmaßnahmen für den Juchtenkäfer (Osmoderma eremita) im Berggarten Hannover. B.Sc. thesis (Hannover: Leibniz Universität).

Magherini, R., and Nin, S. (1993). Research on rooting of selected Tilia spp. Acta Hortic. 331, 259-263. https://doi.org/10.17660/ ActaHortic.1993.331.34.

Morsink, W.A.G., and Smith, V.G. (1974). Root and shoot development on cuttings of basswood (Tilia americana L.) as affected by auxin treatment and size of cuttings. Can. J. For. Res. 4, 246-249. https:// doi.org/10.1139/x74-036.

Osterc, G., and Štampar, F. (2008). Initial cutting length modifies polyphenol profile in Castanea cuttings during the root formation process. Eur. J. Hortic. Sci. 73, 201-204.

Osterc, G., Petkovsek, M.M., and Stampar, F. (2016). Quantification of IAA metabolites in the early stages of adventitious rooting might be predictive for subsequent differences in rooting response. J. Plant Growth Regul. 35, 534-542. https://doi.org/10.1007/s00344-0159559-9.

Pijut, P.M., Woeste, K., and Michler, C.H. (2010). Promotion of adventitious root formation of difficult-to-roothardwood tree species. Hortic. Rev. 38, 213-251. https://doi.org/10.1002/9780470872376. ch6.

Roulund, H. (1973). The effect of cyclophysis and topophysis on rooting ability of Norway spruce cuttings. Forest Tree Improvement 5, 21-41.
Seegert, A. (2011). Eine Frage, die Gemüter erhitzt - Überlegung zur Kompletterneuerung der Berggarten-Allee in Herrenhausen. Stadt und Grün Heft 4.

Spethmann, W. (1985). Grenzen der vegetativen Vermehrung in der Forstpflanzenzüchtung durch Alterung und nicht optimierte Vermehrungsverfahren. Vorträge für Pflanzenzüchtung 8, 149-159. "Züchtung bei vegetativer Vermehrung", Geisenheim, 28.2-1.3.1985, AG Pflanzenzüchtung, Gesellschaft für Pflanzenbauwissenschaften.

Spethmann, W. (2005). Use of long cuttings to reduce propagation time of rose and fruit rootstocks and street trees. Comb. Proc. Int. Plant Prop. Soc. 54, 223-231.

Spethmann, W. (2007). Increase of rooting success and further shoot growth by long cuttings of woody plants. Prop. Ornam. Plants 7, 160-166.

Spethmann, W. (2015). Long cuttings: A novel method to propagate woody plants. In Plant Propagation Concepts and Laboratory Exercises, $2^{\text {nd }}$ edn., C.A. Beyl, and R.N. Trigiano, eds. (CRC Press, Taylor and Francis Group), p. 241-245.

Wang, J.W., Park, M.Y., Wang, L.J., Koo, Y., Chen, X.Y., Weigel, D., and Poethig, R.S. (2011). MiRNA control of vegetative phase change in trees. PLoS Genet. 7, e1002012. https://doi.org/10.1371/journal. pgen.1002012.

Received: Feb. 14, 2019

Accepted: Mar. 22, 2019

Addresses of authors:

Traud Winkelmann ${ }^{1, *}$, Wolfgang Spethmann ${ }^{1}$ and Anke Seegert ${ }^{2}$

${ }^{1}$ Leibniz Universität Hannover, Institute of Horticultural Production Systems, Woody Plant and Propagation Physiology, Herrenhäuser Straße 2, D-30419 Hannover, Germany

${ }^{2}$ Leibniz Universität Hannover, Institute of Landscape Architecture, Herrenhäuser Straße 2a, D-30419 Hannover, Germany / Herrenhäuser Gärten, Herrenhäuser Straße 4, D-30419 Hannover, Germany

* Corresponding author;

E-mail: traud.winkelmann@zier.uni-hannover.de Tel.: 0049511762 3602; Fax: 00495117623608 